\title{
Line Development and the Passenger Steamboat Trade on Lake Ontario and the Upper St Lawrence River, 1829-1875
}

\section{Walter Lewis}

\begin{abstract}
À l'aide d'une étude de cas des opérations sur la rive nord du lac Ontario et du haut Saint-Laurent au milieu du 19e siècle, cet article étudie l'évolution des différents modèles de service offerts par les compagnies de navigation. Entre autres, ces modèles comprenaient une combinaison de navires détenus en propriété et affrétés, une succession d'entrepreneurs appuyés par des sous-traitants et une des premières conférences de navigation. La forme définitive, mais pas nécessairement inévitable, était celle d'une entreprise constituée en société qui a acquis les actifs des divers propriétaires de navires indépendants.
\end{abstract}

One of the most significant developments in the application of steam technology to shipping has been the emergence of shipping lines. Although to some degree these had been present on the North Atlantic from the debut of the New YorkLiverpool sailing packets in 1817, the emergence of lines as a significant pattern of marine organization was largely a function of the new steam technology. ${ }^{1}$ Generally, shipping lines have been defined as consisting of two or more vessels making regular trips at stated intervals on a single trade. Incumbent upon such a line service is the adherence to an advertised schedule irrespective of the fact that a profitable cargo may not have been loaded at the fixed time of departure. ${ }^{2}$

\footnotetext{
1 P.N. Davies, "The Development of the Liner Trades," in Keith Matthews and Gerald Panting, eds., Ships and Shipbuilding in the North Atlantic Region (St John's: Memorial University of Newfoundland, 1978), 180-2.

2 Ibid., 180; Louis C. Hunter, Steamboats on the Western Rivers, (Cambridge, MA: Harvard University Press, 1949), 320-1.
}

The Northern Mariner / Le marin du nord, XXIX, No. 2 (Summer 2019), 135-48 


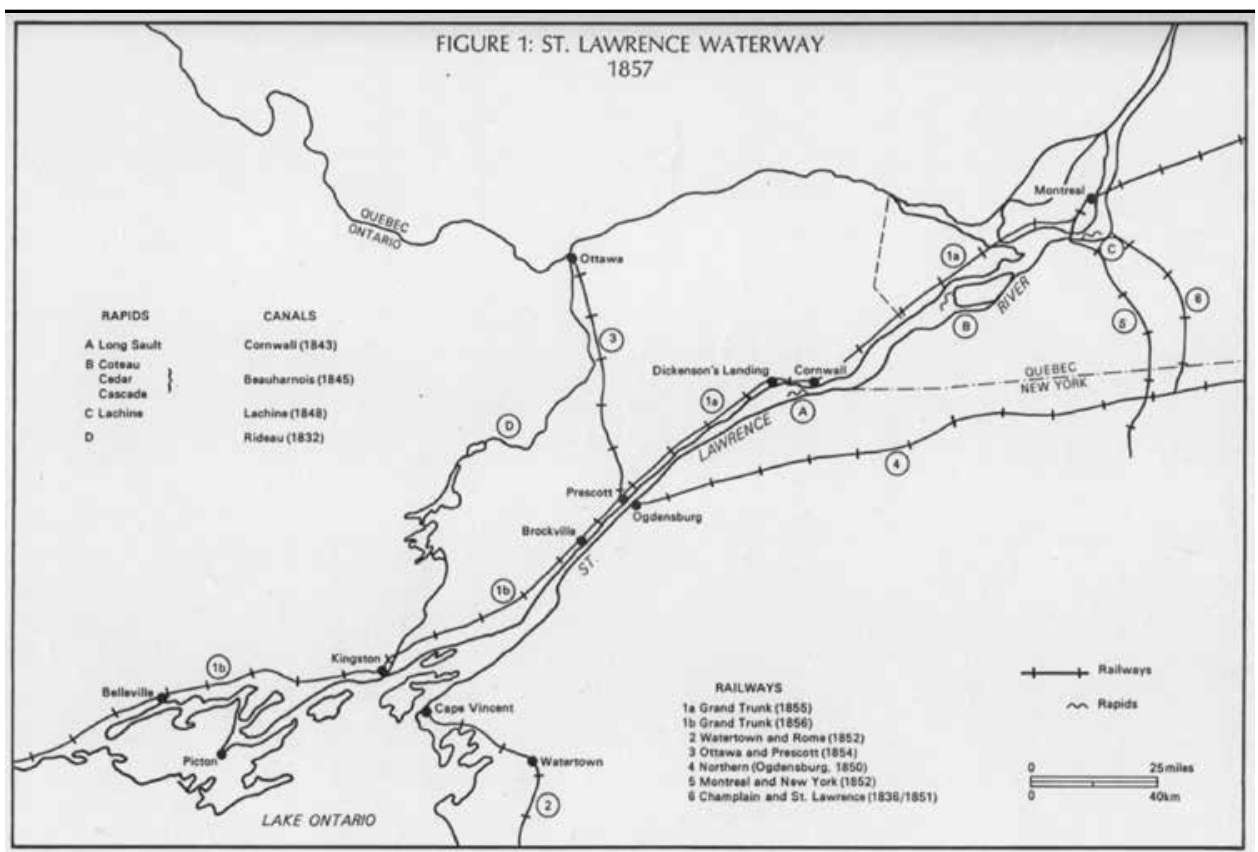

In marine history lines have usually been analysed in the context of the development of large shipping corporations, or as the principal components of international shipping conferences. Studies of companies like Cunard, the Peninsular \& Oriental, or the lines operating on the New England-Maritimes trades reveal a remarkably similar pattern. Regular line service was seen as desirable. Investors, frequently including shipowners already in the trade, then secured an act of incorporation. While some vessels might have been chartered this was only a transitional phase, until the company raised the capital to build or buy. One variation saw stock issued to businessmen who sold vessels to the new firm. In either case, the line and the company were closely identified until the company gathered the strength to expand into other trades. ${ }^{3}$

Although this model of line development has its place in the history of the St. Lawrence and Lake Ontario trades, it is the final stage, following over thirty years of line development. Moreover, none of the Canadian Great Lakes lines were operated by corporations until 1861 . This was the direct result of a legislative disinclination to incorporate, which had its roots in the South Sea Bubble fiasco of the early 1700s. Prior to 1850 , in both Great Britain and Canada, shipping companies were incorporated only when they appeared to serve political ends, such as expediting the mails, and where the investors risked large amounts of capital on relatively experimental technology. Nothing on the Great Lakes even

\footnotetext{
${ }^{3}$ See for example Francis E. Hyde, Cunard and the North Atlantic, 1840-1973:AHistory of Shipping and Financial Management, (Atlantic Highlands, NJ: Humanities Press, 1975); Boyd Cable, A Hundred Year History of the P\&O: Peninsular and Oriental Steam Navigation Company, 1837-1937, (London: Ivor Nicholson and Watson, 1937), or A.L. Johnson, "Boston and the Maritimes: A Century of Steam Navigation" (PhD thesis, University of Maine, 1971).
} 


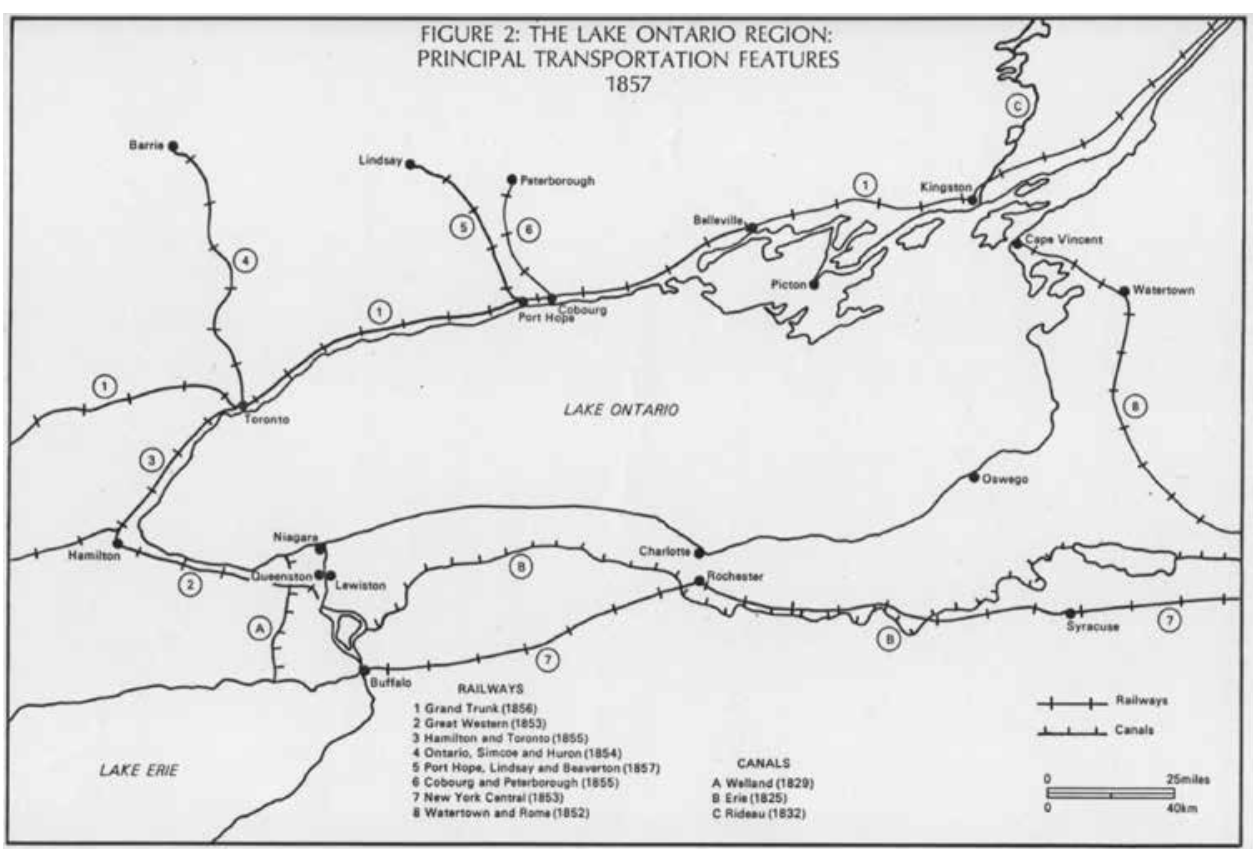

approximated that level of risk. ${ }^{4}$

An alternative pattern of development was described by Hunter as typical of lines on the Ohio-Mississippi system. There, lines were alliances of independent entrepreneurs working either on a co-operative basis or by formal written agreements between several boats to run in formation, and possibly set uniform rates, jointly advertise or even in some cases pool profits. However, according to Hunter, these arrangements rarely lasted for long, sometimes not even a full season. There was little incentive for proprietors to stay "in line" when they as individuals were losing money, or when breakdowns delayed their departure until it conflicted with the next in line. This situation changed after the Civil War as incorporated firms came to dominate the Ohio- Mississippi trades as well..$^{5}$

What follows is a regional case study of the passenger steamboat trade between the foot of practical navigation on the upper St Lawrence, along the north shore of Lake Ontario to an upper terminus which shifted over the years from Niagara to Toronto and then on to Hamilton. The number of lines working this route varied over the years from one to three, sometimes splitting the service at Kingston and occasionally competing with each other. However, even when the trade was divided, a similar organizational pattern was established on the upper and lower routes. It is hoped that the experience of these lines, over a 46 year period may prove a useful starting point for a comparative analysis of line development on the shorter, coastal and inland lake and river steamboat trades.

4 R.C.B. Risk, "The Nineteenth-Century Foundations of the Business Corporation in Ontario," University of Toronto Law Journal 23 (1973),270-2; Davies, 185.

5 Hunter, Steamboats on Western Rivers, esp. 321-35. 
By the late 1820 s there was still no serious competition within the steamboat trade on Lake Ontario. Indeed there would have been little point to such activity as the vessels could be deployed in such a way that plenty of opportunities were available to all.

In 1829 the three Prescott-Niagara boats started advertising as the "Lake Ontario Canadian Line of Steamboats." Given that two of the proprietors were brothers, Robert and John Hamilton of Queenston, this development is hardly surprising. Partners until 1827, they had been the first on the Canadian side to run vessels on complementary schedules. In announcing the line two years later, neither the Hamiltons nor the owners of the Niagara were undertaking much of a risk. In fact they may have saved some money by jointly paying for the handbills and newspaper advertising. In addition, they maintained a common set of rates and agreed to a schedule which did not overlap at any of the ports they served. ${ }^{6}$

This simple co-operative arrangement persisted for as long as the primary condition of its existence held: minimal competition. For three years the vessels enjoyed a profitable association. However, their very success stimulated new steamboat construction even as these vessels began to show signs of age. By 1832 the launch of several new boats, including one owned by John Hamilton, had resulted in overcrowding on the trade. Although there was a concerted effort to orchestrate departure times on the Prescott-Niagara route, the uncertainties of steamboat operation in a generation of vessels plagued by frequent mechanical breakdowns inevitably led to confrontations and hard feelings. This, combined with the seizure of the Niagara by her creditors and a falling out between the Hamilton brothers over a contract for the transportation of the troops, meant the end of this simple co-operative venture. ${ }^{7}$

One element which distinguishes it from these other lines which followed was the relative absence of contractual obligations. Much of this lies in the fact that the government contracts, which would have a major influence in the development of lines after the rebellions were relatively unimportant. In fact, the Troop contract involved one and only occasionally two vessels and thus was not even able to accommodate an entire line.

This situation was dramatically altered in the wake of the shots fired around Montgomery's Tavern in 1837. The continuing unrest in Upper Canada meant that large numbers of troops would be shipped into and around the region to the direct benefit of those holding the exclusive rights to supply steamboat transport to the military. Concurrently, in the wake of several years of uncertain profits, the owners

\footnotetext{
6 Kingston Chronicle, 18 April 1829, 7 May 1831; Brockville Recorder, 25 May 1830; Colonial Advocate, 8 Nov. 1827.

7 H.A. Musham, "Early Great Lakes Steamboats: Westward Ho! and Flush Times, 1831-1837," American Neptune 7: 1 (1947), 42-65;J. Ross Robertson, Landmarks of Toronto, (Toronto: J. Ross Robertson,1896) II, 856-60; Brockville Recorder, 3 May, 8 Nov. 1832; H.J. Boulton to Col Rowan, 10 Nov. 1832, LAC, RG 5, Al, v. 123;Robert Hamilton to ?, 16 Mar. 1832, LAC, RG 8, I, C Series, v. 377, 159-61 ; Robert Hamilton to ?, 17 Apr. 1832., ibid., 165-73.
} 
of the small, joint stock association steamboats were desperate for the kind of guaranteed income that a multi-seasonal charter could bring. Let someone else take the risks in the depressed post-rebellion economy. Thus, when John Hamilton approached the managing committees of several of these vessels in the winter of 1838 they were quite eager to place the steamboats under his management. $\mathrm{He}$ then neutralized the threat of competition from other powerful interests in the local trades by agreeing to share a quarter of the spoils with the Jones family of Brockville and by chartering one vessel from the Gildersleeve interests in Kingston. ${ }^{8}$ The "Lake Ontario and River St Lawrence Line" floated by Hamilton that spring was an amalgam of two vessels owned by him, four which were chartered and the two vessels which the Jones family promised to supply at their own risk.

Not only would this combination succeed in capturing the most valuable Troop transportation contract since the War of 1812, but it also attracted a second opportunity. The late 1830s was a period of dramatic change for the British Post Office, one of the highlights of which was the triumphant coming of age of ocean steamships. Due in large part to political pressure the post office almost immediately began contracting with what would become some of the major steamship lines in the British Empire: Cunard, the Peninsular Steam Navigation Co., and the Royal Mail Steam Packet Company. Demand for frequent, rapid mail service in the Canadas was accentuated by the rebellions. With pressure from the colonial administrators and the example of the Atlantic and Peninsular mails before him, the deputy post master-general for British North America offered Hamilton a contract to carry the mails. Post Office requirements, however, proved too inflexible for the operator of a service whose primary responsibility was to deliver troops whenever and wherever the military wanted them. Consequently Hamilton settled for an interim, informal arrangement which would persist for another three years. ${ }^{9}$

When the Jones's quickly reneged on their part of the contract, the line settled into a pattern of owned and chartered vessels. Control over operations was in the hands of two men, John Hamilton, the 36 year old entrepreneur, and his ex-captain and general manager, William Meneilly.

Of all the variations which appeared on the trade prior to 1861, this line most closely paralleled the origins of companies, like the Peninsular Steam Navigation Company, whose unincorporated partners had chartered steamers to flesh out their first line service. But in fact, they differed in two respects. Hamilton failed to secure the mail contract when next it was offered him while the Peninsular and Oriental was incorporated as a quid pro quo for an extension of their mail contract through to India. Subsequently, in 1840 , even as the P \& O began to develop into one of the world's largest shipping corporations, Hamilton found himself in the position

8 For a more detailed analysis of the subsequent lines see Walter Lewis, "Until Further Notice":The Royal Mail Line and the Passenger Steamboat Trade on Lake Ontario and the upper St Lawrence River, 1838-1875 (MA thesis, Queen's University, 1983); Jones V. Hamilton, Upper Canada, Queen's Bench Reports, v. 3, 170-2; Kingston Chronicle and Gazette, 11 Feb. 1837, 11 Apr. 1838.

9 Davies, "Development of Liner Trades," 183-4.; Kingston Chronicle and Gazette, 1 Aug. 1838. 
of having to come to terms with his successful competitor. Donald Bethune was an extremely ambitious and aggressive entrepreneur who lacked the financial resources to float a new line on his own. After some negotiation, a major portion of the line was sub-contracted to Hamilton and another partnership. Fortunately for Hamilton, the expiration of several of his charters released him from most of his previous obligations with remarkably few penalties, and the Lake Ontario and upper St Lawrence trade entered a new era of decentralized line management. ${ }^{10}$

The new line, advertised initially as the Royal Mail Steam Packets (there being nothing to prevent its management from appropriating a good name), was

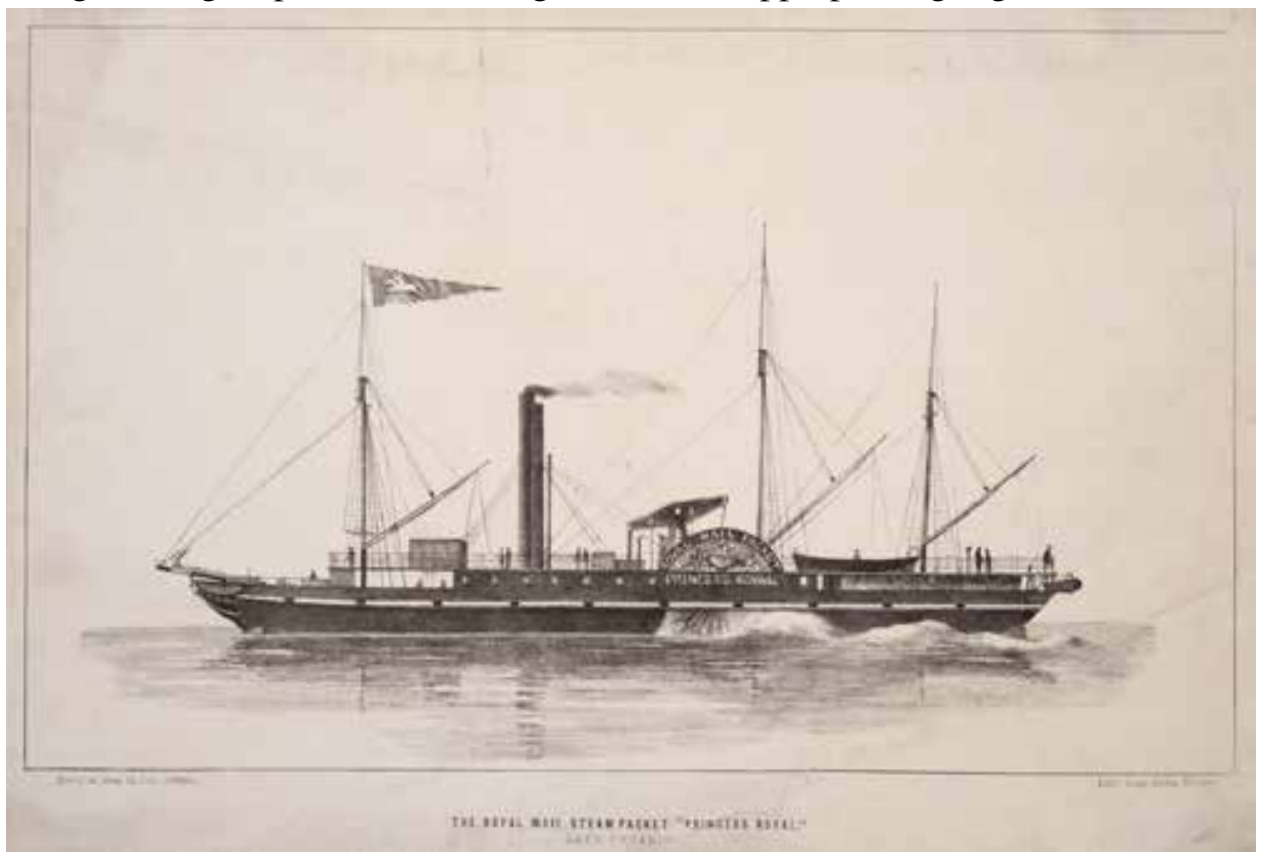

Bethune's Princess Royal (Toronto Public Library)

effectively operated as two lines. Bethune dominated the Toronto to Kingston trade while the run down river from Kingston was sub-contracted to Hamilton. By tendering two contracts in 1846, the Post Office recognized the split at Kingston and the fact that the St Lawrence canals were opening the river to Montreal. Consequently, although the lake line always required three vessels, the river line gradually grew from two in 1841 to four by 1846 .

Despite this difference the two lines were parallel in structure. Prior to 1846 there was one principal contractor and two and later three sub-contractors. ${ }^{11}$

10 Davies, "Development of Liner Trades," 183. Cable, History of $P \& O$; Peter Baskerville, "Donald Bethune's Steamboat Business: A Study of Upper Canadian Commercial and Financial Practice," Ontario History, 67 (1975), 135-49; Lewis, "Until Further Notice," 35-42.

11 N.S. Griffin to Hon D. Daly, 12 Oct. 1846., LAC, RG 3, Series 1, v. 8, 300-1; Kingston Chronicle and Gazette, 14 July 1841, 16 Apr. 1842, 15 July 1843; British Whig, 4 Sept. 1847. 
In the case of both lines, roles were defined in the context of the three principal contracts available to steamboat proprietors: the mail, troop and indigent emigrant contracts. Control of these agreements gave the contractors considerable influence over the operation of the line. At the same time, the contracts themselves presented the participants with certain givens. In particular, the mail contracts specified the days and times of departure and arrival, the ports which would have to be served, and set out penalties for non-compliance. Some agreement then needed to be reached within each line as to how the proceeds of this contract were to be divided, whose vessels were to be used in case of mechanical breakdowns, which days

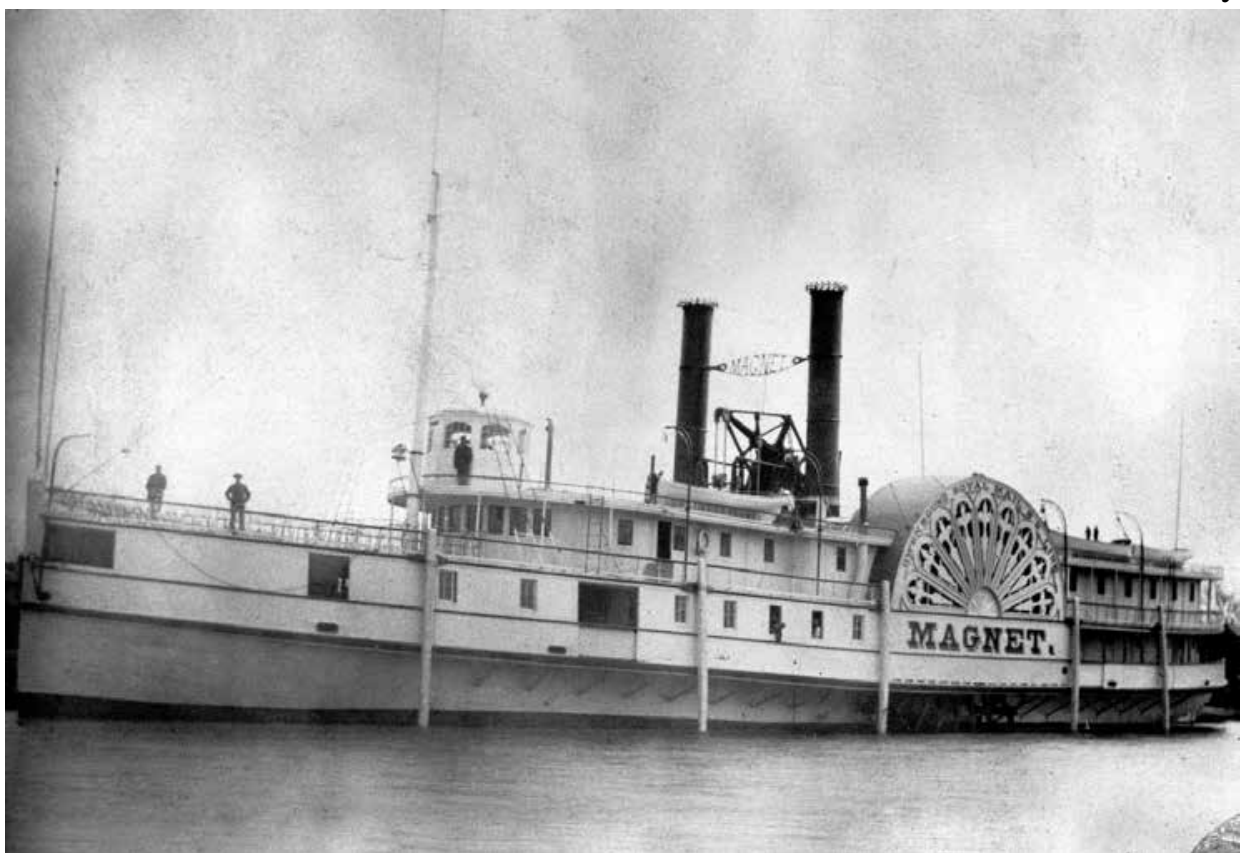

Magnet (Library and Archives Canada)

individual boats took, the rates to be charged, action in the case of competition, and the conditions on which services were supplied. Principal contractors were at a distinct advantage in these negotiations by controlling participation in the line. ${ }^{12}$

By its very nature, the sub-contracting model of line operation was based on a balance of power - the contractor controlling certain sources of income which supplemented and stabilized the revenue from independent passenger and freight operations, and the sub-contractor providing some of the vessels necessary to maintain the service. Failure of a sub-contractor meant choosing among the potential replacements. Failure of one of the principal contractors, Bethune, offered

12 Report of the Commissioners appointed to Enquire into the Affairs of the Post Office in British North America, D25, "Contract for Steamboat Mail between Toronto and Dickenson's Landing," Province of Canada, Legislative Assembly, Journals, 1846, App. F. 
the others associated with the lines an opportunity to increase their influence by jointly tendering for the next contract. Even the unexpected revival of Bethune's fortunes failed to deflect them from this purpose..$^{13}$

The sub-contracting model of line organization which prevailed throughout the 1840s represented a substantial decentralization of control relative to Hamilton's earlier combination of owned and chartered vessels. Several interests were active within the line, each managing its own vessels and negotiating the general terms of interaction. However, general dissatisfaction with the distribution of power within these agreements, led the sub-contractors to seize the first opportunity to change the system. A subsequent half season of bitter competition with Bethune, and the prospects of the fight escalating the following spring, led all parties -to meet in Kingston in 1850 to work out an alternative. The agreement reached there essentially changed the direction of the development of the lines. ${ }^{14}$

Agreements in restraint of competition were scarcely an innovation on the inland waters of North America. The same economic circumstances which had led to John Hamilton's line by 1839 had seen the negotiation of price fixing agreements on the upper Great Lakes and even among the forwarders on the St Lawrence. ${ }^{15}$ However, what emerged in Kingston involved much more than simple price fixing. The agreement signed by the attending parties bore a close resemblance to what by the end of the century would become known as a cartel. This concept goes well beyond the notion of price fixing into such activities as "market sharing or output limitation, joint selling, patent and process cross-licensing and profit pooling." 16 Essentially though, a cartel is defined as an association of relatively independent firms which combine in order to limit competition significantly. This combination is regulated by some "explicit contractual organization or relationship." ${ }^{17}$ Before the conference ended in 1850 its participants signed formal articles of agreement which would form the basis of the new cartel. ${ }^{18}$

Several characteristics were unaffected by the new arrangements including independent liability, basic schedules, and the freedom to negotiate with different agents at particular ports. On the other hand major innovations included a formal joint decision-making body which was to meet monthly in Kingston to transact business - in particular "fixing from time a scale of fares for passengers - dividing

13 T.A. Stayner to Hon. James Leslie, 4 Oct. 1849, LAC, RG 5, Cl, v. 275, \#1946.

14 British Whig, 18 Apr., 15 May, 25 May, 27 June, 26 July 1849; Donald Bethune Papers, Articles of Agreement ..., 25 Apr. 1850, LAC, MG 24, D24.

15 History of the Great Lakes, (Chicago: J.H. Beers, 1899), I, 443-4; Upper Canada, House of Assembly, Appendix to the Journals, 1839, II, pt. 2, p. 840; British Whig, 3 Oct 1845; Alfred E. Kahn, "Cartels and Trade Associations," in International Encyclopedia of the Social Sciences, (Macmillan, 1968), II, 320.

16 Kahn, ibid.

17 Ibid.

18 British Whig, 29 Apr., 30 Apr., 6 May 1850; Articles of Agreement..., 25 Apr. 1850, LAC, MG 24, D24. 


\section{ROUYAL MALL THROUGH LDEE,}

Kingston, Toronto, Hamilton, Lewiston, Niagara Falls, Buffalo, Cleveland, Detroit, Chicago and Milwankie,
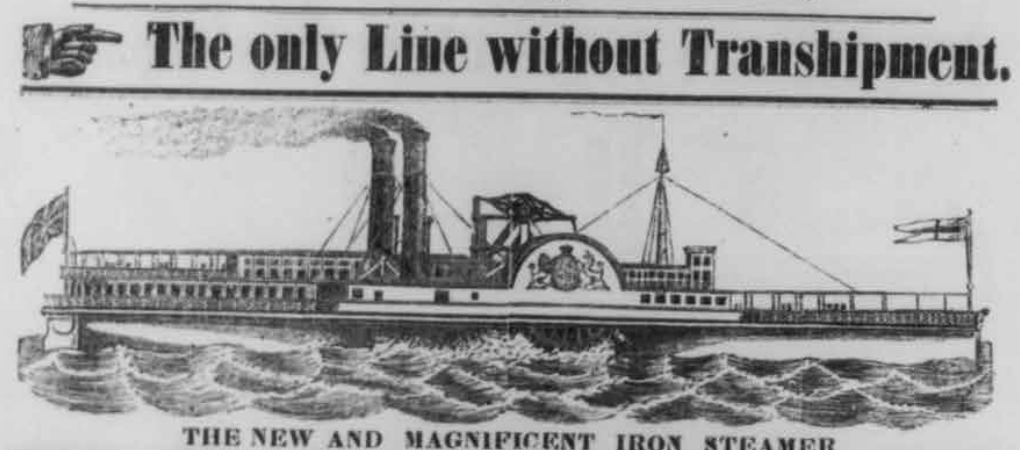

THE NEW AND HAGNIPICENT IRON STEAMER

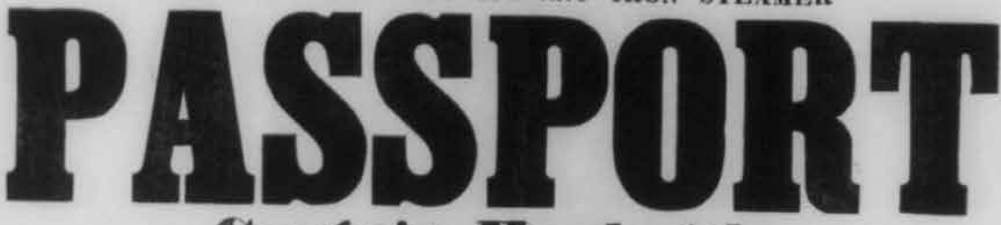

Captain Harbottle,

Now in the Canal Basin, MONTRE, I. will heve at NINE o'clock A, M., and LACIIINE the arrival of the Train, leaving the Station Bouaventure Street at NOON on.

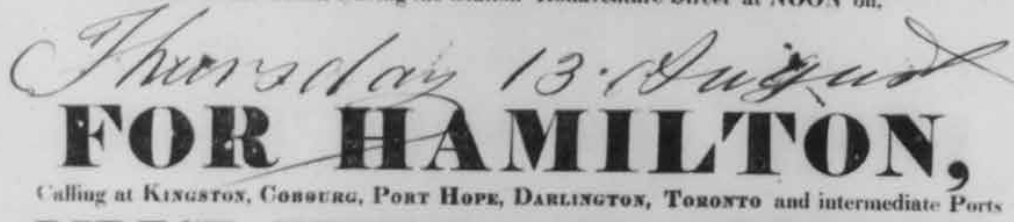

DIRECT WITHOUT TRANSHIPUENT.

60- The PAsspoti'T is fitted up with Saloous and State Rooms, elegantly lurnished; and for speed aud Coufort is not surpassed.

Freight forwarded with the greatest Dispatch, at IModerato rates.

For freight or passage, apply at the Office $\mathbf{4 0}$ MeGill Street, or at the Office coruer of (ires) Vun Street, Canal Banil.

\section{A. Minror, Agent.}

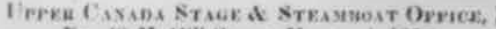

Ye. 10 Medill Stree4, Noutreal, IR57.

Note that the illustration of Passport in this broadsheet was generic. Passport had one stack and

did not have a walking beam although some of her line mates did. (Library of Congress) 


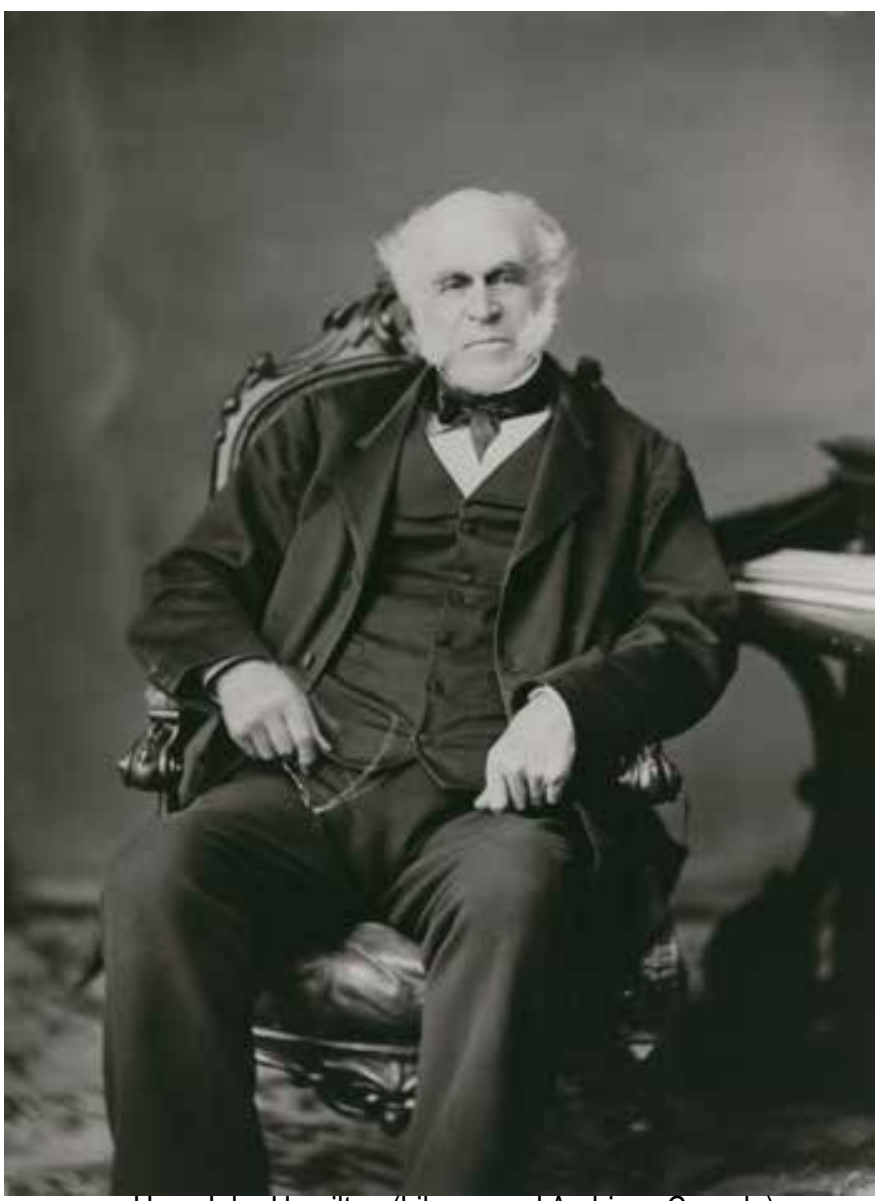

Hon. John Hamilton (Library and Archives Canada)

receipts [and] auditing accounts." ${ }^{19}$ To resolve potential impasses the arrangements assigned votes to each participant generally in proportion to the number of vessels they represented within the terms of the agreement. Shared expenses included the joint operations of agencies in Montreal, Quebec, Niagara Falls, and Buffalo, and an independent Kingston accountant who was empowered to examine the books of the participating vessels. He was particularly concerned with the pooling and redistribution of 60 per cent of each vessel's freight and passenger revenues as well as the receipts from the troop contract. During subsequent annual renegotiations these pooling arrangements would expand to incorporate the postal contract. ${ }^{20}$

Given that two of the signatories were freight forwarding partnerships, one of which was anxious to run a line of freight steamers on Lake Ontario, the parties gave some attention to limiting the solicitation of business outside their

19 Ibid., section 5.

20 Ibid., sections 5, 6, 8, 10, 11, 23. 
particular specialties, this in the case of the Royal Mail and Through Lines being the passenger and express trades. They also agreed to give a kickback to Bethune for each passenger transferred from a subsidiary trade. ${ }^{21}$

The process of annual renegotiation, which had the potential for being as disruptive as the regular tendering of the mail contract had been, actually facilitated the orderly withdrawal from the trade of some of the interests involved. Several of the forwarders moved into the railway contracting business, while D. Bethune \& Co. went bankrupt (this time largely a function of dishonesty in the company office). For a time the annual meeting began to function as a shipping conference, with the management of other lines operating the length of Lake Ontario participating in the deliberations. Few details, unfortunately, have survived regarding this development. ${ }^{22}$

Ultimately the cartel failed because of the completion of the Grand Trunk Railway and the financial panic of 1857. Together they represented one of the worst possibilities a business organization can face: a sharp short-term decline in demand coupled with a dramatic increase in the supply of its particular service. Moreover, no matter how poorly the railway fared in the marketplace, the government was prepared to keep the line out of receivership using a generous selection of concessions, subsidies and financial sleights of hand. But while the railway would not be allowed to go bankrupt one by one the region's shipowners were suffering exactly that fate..$^{23}$

After most of his associates either voluntarily or involuntarily withdrew from the trade, John Hamilton found himself in sole control of the line again. But despite using virtually every competitive edge at his disposal, including at one stage an agreement with the Grand Trunk, Hamilton could not escape the fate of most of the others. In the spring of 1861 all his property was assigned to three trustees in order to avoid formal bankruptcy proceedings..$^{24}$

Nevertheless, to conclude the study at this point would be to cast it as a classic tragedy, with the protagonist succumbing in the end to the overwhelming power of

21 Ibid., sections 15, 16, 19.

22 Gerald J.J. Tulchinsky, The River Barons; Montreal Businessmen and the Growth of Industry and Transportation, 1837-1853, (Toronto: University of Toronto Press, 1977), 42-3; Henry C. Klassen, L.H. Holton: "Montreal Businessman and Politician, 1817-1867," (PhD thesis, University of Toronto, 1970), 1128-9; Patterson V. Holland, Grant's Chancery Reports, v. 7, 2-3; British Whig, 23 Apr., 30 Apr. 1850, 13 Apr., 18 Apr., 19 May 1854;Great Western Railway, General Meetings of Shareholders, Minute Book, 12 Mar. 1856, LAC, RG 30, v. 1.

23 G.R. Stevens, Canadian National Railways, (Toronto: Clarke, Irwin, 1960) I, Chap. IX; A.W. Currie, The Grand Trunk Railway of Canada, (Toronto: University of Toronto Press, 1957), 47-8; Robertson, Landmarks of Toronto, II: XXX; Daily News, 14 Nov. 1857, 7 Apr. 1858.

${ }^{24}$ Canada, Commission Appointed to Inquire into the Affairs of the Grand Trunk Railway, Report, App. IV, 33-5; La Societe de Navigation du St Laurent \& du Richelieu, Minutes, 5 avril 1860, Queen's University Archives, Canada Steamship Lines Papers [CSL Papers], v. 15; Dun and Bradstreet Papers, R.G. Dun \& Co. Credit Ledgers, Canada, v. 15, 104, Harvard University, Baker Library; Weekly British Whig, 21 Mar. 1861. 
the forces aligned against him. The finality implicit in such an interpretation would be a dangerous oversimplification. Indeed, the elements of continuity are striking. In 1861 and for years thereafter the same management team ran the same fleet on the same lines. If the capital and ownership were different, this was nothing unusual. As we have seen, the line had undergone regular shifts in both ownership and organization over the course of its history.

In fact, within a few weeks of Hamilton's assignment a group of promoters, led by his Montreal agent and one of his sons were busy advancing a company to acquire Hamilton's steamboat interests. Investors of two distinct types subscribed for stock: the agents and captains who had been involved in the Royal Mail Line the previous few years, and a group of Montreal businessmen associated with Hugh Allan. Allan controlled an unused company charter which allowed the new firm to organize immediately without the risks associated with unlimited liability partnerships or associations. Subsequently, Allan became the company president and would dominate the history of the Canadian Navigation Company for fourteen years until he arranged a merger with the more profitable Richelieu Company. ${ }^{25}$

Closely linked to the takeover of the line by the Canadian Navigation Company were several innovations in management. Most of the decision making was assumed by the directors and the paper work by the secretary-treasurer, the line's former Montreal agent. Hamilton was retained for a number of years to act as General Manager of until, after a major expansion in the late 1860s, the decision was taken to employ a superintendent whose duties encompassed most of those previously handled by him. Other responsibilities of the superintendent included the direction of salvage operations (previously left to the insurance companies), some hiring, and the supervision of vessels being constructed for the firm (a task hitherto usually assigned to the man who was to be the first commanding officer) ${ }^{26}$

At the same time the corporation proved much more adept at raising capital for expansion than had any of the individual proprietors or partners who had participated in earlier lines. The traditional method of purchase was still available, payment in a limited number of large sums over a period of three to four years, secured by a vendor's or bank mortgage. While not authorized by its charter to sell bonds, the issuance of stock raised two new possibilities. The first of these was the exchange of real capital, particularly steamboats, for shares in the company. While in many respects this parallelled giving an owner a vote in the deliberations of the managing committee of a cartel, here the option of withdrawing after a year did not

25 Weekly British Whig, 11 Apr., 19 Apr. 1861; Province of Canada, Statutes, 20 Vic., c. 169, 22 Vic., c. 125. They could have used the general incorporation principles of $23 \mathrm{Vic}$, c. 31 which would have made Allan's charter unnecessary but to get the boats they had to move quickly and this statute involved delays of a minimum of three months.; Canadian Inland Steam Navigation Company, Dividend Book, v. 15, 12 June, 16 June 1874, 16 Jan., 5 Feb. 1875, C.S.L. Papers, v. 172,; see also Lewis, Until Further Notice, chap. V.

26 Weekly British Whig, 26 Apr. 1861. British Whig, 4 Aug. 1869, 25 Apr. 1868, 12 Mar. 1870. Daily News, 10 July 1872, 26 Nov. 1873. 
exist. Moreover, with parliamentary approval, it was possible to raise the amount of shares the company was permitted to sell. Both these options would be used by the management of the Canadian Navigation Company. Moreover, throughout its career the company never failed to pay a dividend, a record its chief competition the Grand Trunk Railway never began to match. ${ }^{27}$

Following a policy rather tentatively initiated by John Hamilton in the last desperate season before his assignment, the Company also expanded to absorb new lines. For a period of ten years it leapfrogged the Richelieu Company and ran a summer line from Quebec to the new resorts on the lower St Lawrence and the Saguenay. In 1867 it bought out the capital stock of the last major American steamboat company on Lake Ontario and transferred the vessels to Canadian registry. This expansive tendency, after the company merged with the Richelieu Company, made the new Richelieu and Ontario Navigation Company one of the most aggressive on the lakes, a spirit which it, in turn, would bequeath Canada Steamship Lines. ${ }^{28}$

How then can we begin to draw the experience of the Lake Ontario and Upper St Lawrence passenger steamboat lines into the context of line development elsewhere. Five models of line development have been identified on the upper St Lawrence and Lake Ontario in the period 1829 to 1875, beginning with a loose coalition of vessels running between the same ports on complementary schedules. The second model was a combination of owned and chartered vessels, characterized by centralized management. This was succeeded by the "sub-contract" model, which sacrificed centralized management for a much looser organization with risks more widely spread. The principal difference between this and the "cartel" model was that in the former the contracts imposed a hierarchy while the latter used a distribution of power similar to holding shares in a joint stock company. The final model was that which combined centralized management with diffuse ownership through the medium of the joint stock corporation.

In terms of vessel ownership the lines were much closer to the pattern of development on the Mississippi-Ohio river system than on the deep sea. Much of the reason for that probably lies in the fact that the vessels operating on Lake Ontario were usually required to navigate the St Lawrence locks and were thus limited in size to the capacity of these public works. While the vessels became more expensive in terms of hull construction, as iron was more extensively employed, and in terms of the palatial accoutrements considered essential to attract cabin passengers, the size of the vessel was essentially limited to 250 tons (old measurement). This class of vessel was much more easily financed by individuals than were the increasingly large steamships which came to dominate the ocean

\footnotetext{
27 LAC, RG 12, A1, v. 178, pp. 5-6; v. 206, pp. 299, 307; v. 179, p. 50; Canada, Statutes, 31 Vic., c.

28 British Whig, 29 Oct. 1867, 19 June 1869. Arthur Bueis, Le Saguenay et La Vallee du Lac St.
} 
trades. $^{29}$

Consequently, there was little in the experience of the trade prior to Hamilton's bankruptcy in 1861 to encourage the shipowners either to think in terms of incorporation or to expect that the legislature would be very sympathetic. Unlike the major ocean lines like the Royal Mail Steam Packet Co., the Peninsular and Oriental Steam Navigation Co., or even Allan's Montreal Ocean Steamship Co., the Lake Ontario and River St Lawrence Lines never offered any dramatic departures in service which might have induced governments to offer them the privilege of a limited liability corporation. Nevertheless, unlike the MississippiOhio system, the St Lawrence-Lake Ontario trade would benefit from a series of shipping contracts, beginning with the troop contracts and graduating to those with the post office, which provided a continuing impetus for line members to cooperate. Moreover, the advantages held by those with the contracts were sufficient that they discouraged serious opposition.

Why then should we care about the development of line organization? Essentially the line is a pattern for the organization of shipping, rather than a pattern for ownership. But as such the concept helps to clarify the transition from individual proprietorship or the joint stock partnerships or associations into the modern corporation.

With the exception of a few regional writings, of which this paper is unabashedly one, there is little in the general maritime historiography apart from studies of the emergence of the "liner companies" on the major trades, the North Atlantic being the favourite, with all that these lines have come to mean in terms of speed, regularity, luxury, complex management structures, financial capitalism, and shipping conferences. But what about the secondary trades - the coastal waters and inland lakes and rivers? And what of the lines established in the first half of the nineteenth century, before improvements in technology made many of the long distance liner routes profitable? Did these routes have parallel patterns of development? How similar was the upper St Lawrence and Lake Ontario experience with that on the Hudson River or Chesapeake Bay, or any one of a hundred short trades? And if a closer look was taken at the roots of some of the late nineteenth century's great liner companies, how many would be revealed as the outgrowth of multiple proprietor lines? Although pride of place may still be conceded the great liner companies, perhaps as marine historians we should be looking more closely at their antecedents.

29 See dimensions given in John M. Mills, Canadian Coastal and Inland Steam Vessels, 1809-1930, (Providence, R. I.: Steamship Historical Society of America, 1979), for the river steamboats built after 1843. (eg, Passport, Magnet/Hamilton, Comet/Mayflower or Kingston). 